\title{
Burden on Caregivers of Children with Cerebral Palsy: Predictors and Related Factors*
}

\section{Carga de los cuidadores de niños con parálisis cerebral: predictores y factores relacionados}

Recibido: julio 2 de 2012 | Revisado: octubre 3 de 2012 | Aceptado: octubre 10 de 2012

\author{
ELENA M. MARRÓN ** \\ DIEGO REDOLAR-RIPOLL *** \\ MERCÈ BOIXADÓs ***** \\ RUBÉN NIETO ****** \\ NOEMÍ GUILLAMÓN ******* \\ EULÁLIA HERNÁNDEZ ********* \\ BENIGNA GÓMEZ *********
}

Universitat Oberta de Catalunya, Barcelona, España

doi:10.11144/Javeriana.UPSY12-3.bccc

Para citar este artículo: Marrón, E. M., RedolarRipoll, D., Boixadós, M., Nieto, R., Guillamón, N., Hernández, E., et al. (2013). Burden on caregivers of children with cerebral palsy: Predictors and related factors. Universitas Psychologica, 12(3), 767-777. doi:10.11144/Javeriana.UPSY12-3.bccc

* Acknowledgments: This work has been funded with grant from PSI2008-01124 project of the Plan Nacional of I+D. Ministry of Science and Innovation of Spain. Psinet research group is recognized and supported by the Catalan Government (SGR09-197). We thank all the associations and caregivers who have participated in the study, GerardoOntiveros for his assistance along the research process and Brian McCarthy for English translation.

** Universitat Oberta de Catalunya, Barcelona, España. Departamento de Psicología. Estudios de Psicología y Ciencias de la Educación. Researcher ID: H-6891-2013. E-mail: emunozmarr@uoc.edu

**** Universitat Oberta de Catalunya, Barcelona, España. Researcher ID: F-1736-2011. E-mail: dredolar@uoc.edu

***** Universitat Oberta de Catalunya, Barcelona, España. Researcher ID: H-7324-2013. E-mail: mboixados@uoc.edu

****:**: Universitat Oberta de Catalunya, Barcelona, España. Researcher ID: H-6907-2013. E-mail: rnietol@uoc.edu

******** Universitat Oberta de Catalunya, Barcelona, España. Researcher ID: H-6905-2013. E-mail: nguillamon@uoc.edu

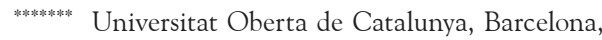
España. Researcher ID: H-6992-2013.

************ Universitat Oberta de Catalunya, Barcelona, España. Researcher ID: H-7350-2013. E-mail: bgomezz@uoc.edu

\section{A B S T R A C T}

The main objective of this research was to explore which factors best predict the occurrence of burden on primary caregivers of children with cerebral palsy (CP). Understanding these factors enables the identification of those caregivers at risk of having their physical and psychological health adversely affected, and the implementation of intervention strategies to reduce the negative impact of caring on parents of children with chronic medical conditions. The study sample consisted of a total of 62 caregivers ( $89 \%$ women) aged between 30 and 54 years (Mean $=41.98, S D=5.64)$. CP affected children were aged between 1 and 17 years $($ Mean $=7.69, S D=4.18)$ and the average degree of disability (\% reflected in the medical record assessed by the Ministry of health, social services and equality of Spain) was 77.098 (scale of 100$)(S D=14.62)$. A burden model was constructed based on multiple linear regressions. The model included the following variables: degree of disability, depression (assessed by Beck Depression Inventory-II) and self-efficacy (measured by the Revised Scale for Caregiving Self-Efficacy). The regression model explained $40.9 \%$ of the total variance. It was found that self-efficacy had a negative linear association with burden, while the degree of disability and depression showed a positive linear association. The most important predictors of caregiver burden were degree of disability, depression and self-efficacy. For this reason, we believe that it is necessary to develop interventions to reduce depression and enhance self-efficacy in parents of children with CP as one of the primary objectives for minimizing the burden on caregivers of disabled children.

Key words authors

Cerebral palsy, caregivers, burden, dependence, depression, self-efficacy.

Key words plus

Clinical Psychology, Health Psychology, Quality of Life, Quantitative Research.

\section{RES U MEN}

El objetivo principal de esta investigación fue explorar cuáles son los factores que mejor predicen la ocurrencia de la carga sobre los cuidadores primarios de niños con parálisis cerebral (CP). La comprensión de estos factores permite identificar cuidadores en riesgo de presentar problemas físicos o psicológicos y la implementación de estrategias de intervención para reducir el impacto negativo del cuidado de los padres de niños con condiciones médicas crónicas. La muestra del estudio consistió en un total de 62 cuidadores ( $89 \%$ mujeres) con edades entre 30 y 54 años $(M=41.98$, 
$D E=5.64)$. Los niños con CP afectados tenían edades entre 1 y 17 años $(M=7.69, \mathrm{DE}=4.18)$ y el grado promedio de discapacidad (\% reflejado en la historia clínica evaluada por el Ministerio de Salud, Servicios Sociales e Igualdad de España) fue de 77.098 (escala sobre 100) $(\mathrm{DE}=14.62)$. Se construyó un modelo de carga basado en regresiones lineales múltiples. El modelo incluyó las siguientes variables: grado de discapacidad, la depresión (evaluada por el Inventario de Depresión de Beck -II) y auto-eficacia (medida por la Escala Revisada de Autoeficacia para Cuidado). El modelo de regresión explicó $40.9 \%$ de la varianza total. Se encontró que la autoeficacia tenía una asociación lineal negativa con la carga, mientras que el grado de discapacidad y depresión mostró una asociación lineal positiva. Los predictores más importantes de la carga de los cuidadores fueron el grado de discapacidad, la depresión y la autoeficacia. Por esta razón, creemos que es necesario desarrollar intervenciones para reducir la depresión y aumentar la auto-eficacia en padres de niños con CP como uno de los objetivos primordiales para reducir al mínimo la carga de los cuidadores de niños con discapacidad.

Palabras clave autores

Parálisis cerebral, cuidadores, carga, dependencia, depresión, autoeficacia.

Palabras clave descriptores

Psicología clínica, psicología de la salud, calidad de vida, investigación cuantitativa.

\section{Introduction}

Cerebral palsy $(\mathrm{CP})$ is a chronic condition defined as a set of functional limitations due to alterations in the development of the central nervous system (Rethlefsen, Ryan, \& Kay 2010; Snider, Majnemer, $\&$ Darsaklis, 2010). It is estimated that the incidence of this disorder worldwide is between 2 to 2.5 cases per 1,000 births (Blair, 2010; Odding, Roebroeck, $\&$ Stam, 2006). Although motor malfunction is the cardinal limitation of CP, the severity of disability is also determined by the presence of sensory, cognitive and social impairments (Bottcher, 2010; Surveillance of Cerebral Palsy in Europe, 2002), leading to significant limitations in self-care functions related to food, personal hygiene and mobility. For these reasons $\mathrm{CP}$ can be taken as a prototype of childhood disability (Raina et al., 2004).

The limitations of those affected can result in demands and requirements for long-term care, which can greatly exceed the normal requirements associated with the early stages of child development.
While care is part of parenting, it can often generate a significant burden when the requirements are excessive and long lasting. This excessive responsibility may adversely affect the physical and psychological health of caregivers (Brehaut et al., 2009; Tucker, Butler, Loyuk, Desmond, \& Surrency, 2009), affecting their social, cultural and professional lives (Grootenhuis \& Bronner, 2009) and possibly reducing their quality of life (Davis et al., 2010).

Zarit, Reever, and Bach-Peterson (1980) defined burden as the impact that caregiving has on the primary caregiver, i.e. the degree to which the caregiver perceives that the different spheres of his/her life (social life, leisure, health, privacy) have been affected by this task (Seguí, Ortiz-Talo, \& de Diego, 2008). Despite its frequent use in scientific literature, the concept of burden has shown some ambiguity and vagueness, and it has been necessary to distinguish between "objective" burden, which refers to changes in the domestic and daily life of caregivers caused by the caring situation, and "subjective" burden, which refers to the attitudes and emotional reactions to the experience of caring (e.g., Myers, 2003). A global understanding of the effects of care on the caregiver should take into account both the physical and mental limitations of the person being cared for, the context in which the care occurs, the consequences arising from the caring role and the factors that may moderate all of the above. Only by taking into account all these elements simple and effective interventions can be introduced to reduce the negative effects and enhance the positive effects of care (Pousada et al., 2009).

The empirical evidence suggests that there is a wide variation in how caregivers adapt to the specific demands of care, which has led a large number of researchers to ascertain the determinants of burden and stress in caregivers. In this sense, it seems that three aspects combine to create a wide variety of circumstances that can cause stress and burden: 1) contextual factors, 2) characteristics of the affected person, and 3) caregiver's characteristics. It is important to understand the influence of these variables on the physical and mental health of the caregiver in order to reduce their negative impact, as much as possible. 
Most of the researches focused on the study of the effects of care, have been done with gerontological populations and, more recently, with patients with brain damage (traumatic brain injury and stroke), psychiatric disorders (mainly schizophrenia) and chronic or long-term illness, such as cancer, multiple sclerosis or spinal cord injury. In all cases, caregivers frequently exhibit burden, and its intensity depends on several factors, which can be grouped into the categories mentioned above:

1. Contextual factors related to social, family and economic support (Artaso, Goni, \& Biurrun, 2003; McCullagh, Brigstocke, Donaldson, \& Kalra, 2005; Rigby, Gubitz, \& Phillips, 2009), limitations of caregiver's life and personal development (Lauber et al., 2003).

2. Characteristics of the affected person, such as severity of disability and the high demands of care (Chang, Chiou, \& Chen, 2010; McCullagh et al., 2005; Rigby et al., 2009; Rivera-Navarro et al., 2009; Vincent, Desrosiers, Landreville, \& Demers, 2009), the severity of the clinical situation (CarodArtal, Ferreira Coral, Trizotto, \& Menezes Moreira, 2009; Gutiérrez-Maldonado et al., 2005), the presence of cognitive and behavioral problems (aggressiveness, difficulty in communicating, etc.) (Artaso et al., 2003; Vincent et al., 2009) or psychological state (McCullagh et al., 2005; Rivera-Navarro et al., 2009; Vincent et al., 2009).

3. Caregiver characteristics, from a demographic standpoint (i.e. gender, occupation, educational level) (Caqueo-Urizar \& Gutiérrez-Maldonado, 2006; Carod-Artal et al., 2009; Gutiérrez-Maldonado et al., 2005; McCullagh et al., 2005; Vicent et al., 2009) to mental and physical health (Carod-Artal et al., 2009; McCullagh et al., 2005; Rigby et al., 2009), training in caregiving tasks (McCullagh et al., 2005) or coping strategies employed (Artaso et al., 2003).

Although current research on the burden of caregivers of disabled children is still scarce, several studies have shown the existence of different factors that contribute to the onset of burden and stress in parents of children with disabilities (e. g., Barlow, Cullen-Powell, \& Cheshire, 2006; Button, Pianta, \& Marvin, 2001; Mobarak, Khan, Munir, Zaman, \& McConachie, 2000; Wang \& Jong, 2004), which largely coincide with those found in the aforementioned researches.

Several authors have found that parents of children disabled by physical or mental illness are more likely to experience burden (Olsson \& Hwang, 2001; Seguí et al., 2008) and experience depression, anxiety and sadness more often than parents of children without disabilities (Barlow et al., 2006; Button et al., 2001; Mobarak et al., 2000; Wang $\&$ Jong, 2004). The presence of these symptoms increases the possibility of burden occurrence in caregivers of children with chronic diseases (Calderón et al., 2011).

The aim of this study, therefore, was to try to understand the complex network of direct and indirect relations that impact on the burden of parent-caregivers of disabled children. We focused on the following objectives:

- To determine the influence of socio-demographic and clinical variables of children in the presence of caregiver burden.

- To determine the influence of socio-demographic and psychological health variables of caregivers and those related with care in the occurrence of burden.

\section{Method}

\section{Participants}

A convenience sample of caregivers of children with cerebral palsy (CP) was selected for this study through different Spanish associations of children with CP (all of them part of ASPACE - Confederación Española de Federaciones y Asociaciones de Atención a las Personas con Parálisis Cerebral y Afines).

The following inclusion criteria were used for these caregivers: (1) to be the father or mother of a child with cerebral palsy (aged less than 18 years) and (2) to be the main caregiver of this child (based on the number of hours of caregiving reported). 
TABLE 1

Independent Variables Assessed and Instruments Used

\begin{tabular}{|c|c|}
\hline Variable & Assessment tool \\
\hline Child's sociodemographic variables (age, gender) & \multirow{3}{*}{ Ad hoc questionnaire } \\
\hline $\begin{array}{l}\text { Primary caregiver's sociodemographic variables (age, gen- } \\
\text { der, educational level, marital status, occupation, employ- } \\
\text { ment status, number of children) }\end{array}$ & \\
\hline $\begin{array}{l}\text { Dedication to care (time spent, aid received from other } \\
\text { family members or caregivers) }\end{array}$ & \\
\hline Degree of child's disability & $\begin{array}{l}\text { Assessed by the Ministry of health, social services and } \\
\text { equality of Spain (\% reflected in the medical record) }\end{array}$ \\
\hline Child dependency assessment & Barthel Index (Mahoney \& Barthel, 1965) \\
\hline Family Functioning & $\begin{array}{l}\text { Family Adaptability and Cohesion Evaluation Scale } \\
\text { (FACES-III) (Olson, Portner, \& Lavee, 1985; Spanish } \\
\text { version: Musitu, Buelga, Lila, \& Cava, 2001). }\end{array}$ \\
\hline $\begin{array}{l}\text { Caregiver coping strategies } \\
\text { Sub-scales: a) Maintaining family integration, coopera- } \\
\text { tion and optimistic definition of the situation, b) main- } \\
\text { taining social support, self-esteem and psychological } \\
\text { stability, and c) understanding the Health Care situation } \\
\text { through communication with other parents and consulta- } \\
\text { tion with the health care team. }\end{array}$ & $\begin{array}{l}\text { Coping Health Inventory for Parents (CHIP) (McCubbin } \\
\text { et al., 1983) }\end{array}$ \\
\hline $\begin{array}{l}\text { Caregivers quality of life } \\
\text { Sub-scales: Physical health, social relationships and envi- } \\
\text { ronment }\end{array}$ & $\begin{array}{l}\text { World Helath Organization Quality of Life (WHQOL- } \\
\text { BREF (Murphy, Herrman, Hawthorne, Pinzone, \& Evert, } \\
\text { 2000; Spanish version: Sánchez-Sosa \& González-Celia, } \\
\text { 2006). }\end{array}$ \\
\hline Caregivers depression & $\begin{array}{l}\text { Beck Depression Inventory-II (BDI-II) (Beck, Steer, \& } \\
\text { Brown, 1996; Spanish version: Vázquez \& Sanz, 1999) }\end{array}$ \\
\hline $\begin{array}{l}\text { Caregivers self-efficacy } \\
\text { Sub-scales: Obtaining respite, responding to disruptive } \\
\text { patient behaviors, and controlling upsetting thoughts }\end{array}$ & $\begin{array}{l}\text { Revised Scale for Caregiving Self-Efficacy (RSCSE). } \\
\text { (Steffen, McKibbin, Zeiss, Gallagher-Thompson, \& Ban- } \\
\text { dura, 2002; Spanish version: Márquez-González, Losada, } \\
\text { López, \& Peñacoba, 2009). }\end{array}$ \\
\hline $\begin{array}{l}\text { Anxiety of caregivers } \\
\text { Sub-scales: State and trait anxiety }\end{array}$ & $\begin{array}{l}\text { State-Trait Anxiety Inventory (STAI). (Spielberger, Gor- } \\
\text { such, \& Lushene, 1970; Spanish version: Tea Ediciones, } \\
\text { 2008). }\end{array}$ \\
\hline
\end{tabular}

Source: Own work.

Exclusion criteria were: (1) to be illiterate or unable to understand Spanish, and 2) to have psychological problems.

The final sample was made up of 62 caregiving fathers and mothers. All of them gave their informed written consent to participate in the study.

\section{Materials}

To ascertain the factors that influence the caregiver burden (dependent variable), the following independent variables were assessed:

The dependent variable (caregiver burden) was assessed using the Zarit Burden Interview (Zarit et al., 1980), which is the most widely referenced scale in studies of caregiver burden. This scale is composed of 22 items that reflect how persons sometimes feel when they are taking care of another person. The total score ranges from 0 to 88 . A high score indicates a higher level of burden.

\section{Procedure}

The participants were contacted through associations of cerebral palsy and were invited to complete the questionnaires (see measures section for a completed description of the variables assessed) with the purpose of assessing the factors potentially related to caregivers' burden. All the members of all the associations affiliated to the 
TABLE 2

Sociodemographic Characteristics of the Sample

\begin{tabular}{lc}
\hline \multicolumn{1}{c}{ Variable } & Caregiver $(n=62)$ \\
\hline Gender, $N(\%)$ & $55(88.7)$ \\
Female & $7(11.3)$ \\
Male & $41.98 \pm 5.64$ \\
\hline Age, Mean (years) & $35(56.5)$ \\
\hline Educational level, $N(\%)$ & $27(43.5)$ \\
\hline Non-universitary studies & 0 \\
$\quad$ Universitary studies & $56(90.3)$ \\
\hline Marital status, $N$ (\%) & $4(6.5)$ \\
\hline Single & $1(1.6)$ \\
Married or similar & \\
Separate & $39(62.9)$ \\
Widow & $23(37.1)$ \\
\hline Employment status, $N$ (\%) & \\
\hline Working & $57(91.9)$ \\
Non working & $5(8.1)$ \\
\hline Other people involve in care, $N$ (\%) & $1.97 \pm 0.75$ \\
\hline Yes & $65.583 \pm 19.28$ \\
$\quad$ No & $96.98 \pm 49.79$ \\
\hline Number of children, Mean & $35.01 \pm 10.23$ \\
\hline \% of care, Mean &
\end{tabular}

Source: Own work.

confederation ASPACE were contacted through the confederation and invited to participate. Caregivers who were willing to participate in the study gave their consent to the association to share their contact data with the research group and they received a call from one of the members of the group. In this telephonic conversation, the main aim of this study and the importance of their participation were highlighted. They were further informed about how much time would be taken up by their participation and the confidentiality of their responses. They were also given an appointment with a researcher during which they could receive help on the testing research team considered more difficult to answer (approximately half of the battery). The rest of the tests were sent to participants via e-mail or by post. They could contact any time through e-mail or phone with the research team for any doubts. All of those who were willing to participate completed the whole battery of tests.

The Ethics Committee of the Universitat Oberta de Catalunya approved all of the study procedures.

\section{Statistical analysis}

All the analyses were carried out using the statistical package SPSS version 19.0. Taking into account the study's purposes, descriptive statistics (means and standard deviation) for the predictive variables and socio-demographic information were also computed.

In order to carry out a thorough analysis of the main factors that might influence the dependent variable (caregiver burden), we decided to build a multiple linear regression model. We implemented 
a strategy for selecting the independent variables in steps, progressively and sequentially adding predictor terms to the model for inclusion.

After the addition of a new predictor, the terms of the model were examined with a sequential exclusion procedure, eliminating those that met the criteria for exclusion. The criteria for inclusion, exclusion and tolerance were set at: pin $\leq 0.05$, pout $>0.1$, tolerance $>0.01$. After selecting the model predictor variables we analyzed compliance with the assumptions of normality, linearity, homoscedasticity and autocorrelation in order to estimate the parameters and their standard errors.

To verify the assumption of normality we used standardized residuals and applied Shapiro-Wilks and Kolmogorov-Smirnov normality tests (with Lilliefors correction). To evaluate the lack of independence, we used the autocorrelation test of Durbin-Watson. Moreover, we assessed collinearity to ensure there was no redundant information that would cause unstable regression coefficients.

\section{Results}

Table 2 summarizes the main demographic characteristics of the caregivers who participated in the study. The mean age of caregivers was 40.95 years $(S D=0.79)$ and $88.7 \%$ were women, $100 \%$ of whom were mothers of children with cerebral palsy. The mean age of the children was 7.69 years $(\mathrm{SD}=4.18)$ and the mean degree of disability was 77.098 (SD = 14.62).

Based on the sequential inclusion procedure, the construction of the final regression model included the variables degree of disability, depression and self-efficacy.

None of the tests applied revealed a significant deviance from the normality assumption of the estimated model $\left(\mathrm{P}_{\mathrm{K}-\mathrm{S}}=0.2 ; \mathrm{P}_{\mathrm{S}-\mathrm{W}}=0.957\right)$. The representation of the residuals indicates that the values were well distributed around 0 , and there were no discrepancies in linearity or homogeneity of variances. The test for serial correlation between adjacent error terms was made using the statistic $d$, obtaining a value of $d=2118$, indicating no autocorrelation. Table 3 shows data from two similar measures of collinearity for each of the variables in the model: The tolerance and the variance inflation factor (VIF). Due to collinearity, problems appear when the tolerances are lower than 0.1 or VIF is greater than 10 , so we can conclude that in our model there were no variables in collinearity.

To assess the fit of the model, we used the coefficient of determination. In our case, the regression explained $40.9 \%$ of the total variation. To check whether this degree of variation was of significance we compared the variance explained by regression to the residual variance. The global significance test of this model was as follows: $F(3,53)=11.516, p<0.001$.

The results showed that the estimated regression equation predictors (degree of disability, depression and self-efficacy) explained a significant proportion of the variability of the caregiver burden. Table 4 presents the coefficients for each predictor variables in the model. As shown in the table, self-efficacy had a negative linear association with the burden, and their contribution to the regression equation is statistically significant $(B=-0.186, p=0.005)$. Meanwhile, the degree of disability and depression showed a significant positive linear association with the caregiver burden $(B=0.193, p=0.015$; $\mathrm{B}=0.452, p=0.002$, respectively).

\section{Discussion}

In this study, the levels of burden of care on parent caregivers of a child with cerebral palsy and its determinants were examined. As we noted in the results section, the most important predictors of the burden in our study were degree of disability, depression and self-efficacy.

An important aspect of caregivers burden is the demands of caring. Different studies have shown that they can directly contribute to both the caregiver's psychological well-being and physical health (Musil, 1998; Raina et al., 2005). Our results show that the degree of disability/dependence of children was a significant predictor of caregiver burden. Several authors suggest that children with disabilities due to chronic illnesses are one of the cardinal factors of the demands of care (Raina et al., 2004, 2005). 
TABLE 3

Collinearity Statistics

\begin{tabular}{lcc}
\hline \multicolumn{1}{c}{ Variables } & Tolerance & VIF \\
\hline Disability & 0.991 & 1.009 \\
Depression & 0.735 & 1.361 \\
Self-efficacy & 0.897 & 1.115 \\
\hline
\end{tabular}

Source: Own work.

As shown in the results section, and in line with other previous studies (Cheshire, Barlow, \& Powell, 2010b; Majerovitz, 2007; Unsal-Delialioglu, Kaya, Ozel, \& Gorgulu, 2009), depression has manifested itself as an important predictor of caregiver burden, showing a significant positive linear association.

On the other hand, our results have shown that anxiety is not a predictor factor in explaining the dependent variable in our study. This is in accordance with the results of Ones, Yilmaz, Cetinkaya, and Caglar (2005) who analyzed a sample of 46 mothers of children with cerebral palsy and 46 mothers of healthy children and found no difference in levels of anxiety between the two groups. These authors concluded that the parents' anxiety could probably be more related to acute life situations than to a long-lasting situation. A long-lasting situation can lead to depressive symptoms, which are more noticeable if the problem becomes chronic.

Self-efficacy has been shown to be related to the psychosocial well-being of parents of children with cerebral palsy (Barlow et al., 2006; Cheshire, Barlow, \& Powell, 2010a). Parents with high selfefficacy have better physical and mental health, better relationships and greater satisfaction in their personal relationships (Florian \& Finder, 2001;
Ketelaar, Volman, Gorter, \& Vermeer, 2008). In our study this variable has been shown to be an important predictor of caregiver burden.

Different studies have shown that parent caregivers of children with cerebral palsy have a diminished quality of life (Davis et al., 2010; Eker \& Tüzün, 2004; Ones et al., 2005; Terra et al., 2011; Tuna, Unalan, Tuna, \& Kokino, 2004). However, our results show that the quality of life of caregivers is not an important predictor of burden. Burden may be a predictor of caregiver's quality of life, but this relation was not explored in the present research.

Our study has also shown that family functioning is not a significant predictor of caregiver burden. However, other studies with caregivers of children with cerebral palsy have found that family functioning can affect the caregiver's well being directly or indirectly through self-perception, social support and stress management (Raina et al., 2005). Also, in a pediatric population, Phipps et al. (2005) have shown that family functioning is one of the predictors of distress experienced by caregivers.

In terms of the coping strategies used by caregivers, we have found that they are not a significant predictor of caregiver burden. Recently, Chronister, Chan, Sasson-Gelman, and Chiu (2010) examined the effect that coping with stressful situations had on the quality of life of caregivers of people with brain damage. These authors have shown that such strategies appear to have a partial role as a predictor of quality of life (Chronister et al., 2010).

In patients with dementia it has been shown that the coping strategies used by caregivers are an

TABLE 4

Coefficients of the Predictors in the Model of Burden

\begin{tabular}{|c|c|c|c|c|c|c|c|}
\hline \multirow{2}{*}{ Variables } & \multicolumn{2}{|c|}{$\begin{array}{l}\text { No standardized } \\
\text { coefficients }\end{array}$} & \multirow{2}{*}{$\begin{array}{c}\text { Standardized } \\
\text { coefficients }\end{array}$} & \multirow{2}{*}{$t$} & \multirow{2}{*}{ Sig. } & \multicolumn{2}{|c|}{$\begin{array}{c}\text { Confidence interval } \\
95.0 \% \text { for B }\end{array}$} \\
\hline & B & Tip. error & & & & $\begin{array}{c}\text { Inferior } \\
\text { limit }\end{array}$ & $\begin{array}{c}\text { Superior } \\
\text { limit }\end{array}$ \\
\hline Constant & 24.88 & 7.98 & & 3.118 & 0.003 & 8.851 & 40.909 \\
\hline Disability & 0.193 & 0.076 & 0.278 & 2.529 & 0.015 & 0.04 & 0.346 \\
\hline Depression & 0.452 & 0.14 & 0.364 & 3.237 & 0.002 & 0.172 & 0.733 \\
\hline Self-efficacy & -0.186 & 0.064 & -0.186 & -2.923 & 0.005 & -0.314 & -0.058 \\
\hline
\end{tabular}

Source: Own work. 
important factor for explaining burden (Cooper, Katona, Orrell, \& Livingston, 2008; Sun, Kosberg, Kaufman, \& Leeper, 2010). Similar results have been found in psychiatric disorders such as schizophrenia (Hanzawa et al., 2010).

In conclusion, there is a wide disparity in how caregivers adjust to the specific demands of care. Of the parameters studied, regarding overload and burden in caregivers, our study finds that two factors are important: The characteristics of the affected person (child with $\mathrm{CP}$ ) regarding the degree of disability and dependence; and the caregiver characteristics regarding mood state and self-efficacy strategies. However, it seems that contextual factors regarding environmental quality of life, social support and family functioning do not have a significant effect on the perceived burden of the caregivers.

Despite the strengths of this study, it presents few limitations. Firstly, the present study has not taken into account the behavior problems of children with cerebral palsy. For some authors, behavioral problems are one of the variables that appear to predict better psychological well-being of caregivers (King, King, Rosenbaum, \& Goffin, 1999). Along these lines, Raina et al. (2005) argues that the behavioral problems of children with cerebral palsy could be established as an important predictor of caregiver psychological well-being, both directly and indirectly through its effects on self-perception and family function.

A second limitation of the study is that we did not include socio-economic factors. In previous research, about the effects that stress has on the health and welfare of people, the economic status seems to be a very important predictor (McEwen \& Gianaros, 2010). However, a study by Raina et al. (2005) found that the impact of such factors on the health and psychological well-being of the parent caregivers of children with cerebral palsy was very weak.

Moreover, it is necessary to keep in mind that the broad-reaching nature of this study limits its ability to extract conclusions of a causal nature. Also, the conclusions reached in this work cannot be applied freely to the general population, since the results are based on individual experiences of caregivers of children with cerebral palsy.

\section{References}

Artaso, B., Goni, A., \& Biurrun, A. (2003). Informal care in dementia: Prediction of burden in female family caregivers. Revista Española de Geriatría y Gerontología, 38(4), 212-218.

Barlow, J. H., Cullen-Powell, L.A., \& Cheshire, A. (2006). Psychological well-being among mothers of children with cerebral palsy. Early Child Development and Care, 176(3-4), 421-428.

Beck, A. T., Steer, R. A., \& Brown, G. K. (1996). BDIII. Beck Depression Inventory. Manual (2nd. ed.). San Antonio, TX: The Psychological Corporation.

Blair, E. (2010). Epidemiology of the cerebral palsies. Orthopedic Clinics of North America, 41(4), 441-455.

Bottcher, L. (2010). Children with spastic cerebral palsy, their cognitive functioning, and social participation: A review. Child Neuropsychology, 16(3), 209-228.

Brehaut, J. C., Kohen, D. E., Garner, R. E., Miller, A. R., Lach, L. M., Klassen, A. F., et al. (2009). Health among caregivers of children with health problems: Findings from a Canadian population-based study. American Journal of Public Health, 99(7), 1254-1262.

Button, S., Pianta, R. C., \& Marvin, R. S. (2001). Partner support and maternal stress in families raising young children with cerebral palsy. Journal of Developmental and Physical Disabilities, 13(1), 61-81.

Calderón, C., Gómez-López, L., Martínez-Costa, C., Borraz, S., Moreno-Villares, J. M., \& Pedrón-Giner, C. (2011). Feeling of burden, psychological distress, and anxiety among primary caregivers of children with home enteral nutrition. Journal of Pediatric Psychology, 36(2), 188-195.

Caqueo-Urízar, A., \& Gutiérrez-Maldonado, J. (2006). Burden of care in families of patients with schizophrenia. Quality of Life Research, 15(4), 719-724.

Carod-Artal, F. J., Ferreira Coral, L., Trizotto, D. S., \& Menezes Moreira, C. (2009). Burden and perceived health status among caregivers of stroke patients. Cerebrovascular Diseases, 28(5), 472-480. 
Chang, H. Y., Chiou, C. J., \& Chen, N.,S. (2010). Impact of mental health and caregiver burden on family caregivers' physical health. Archives of Gerontology and Geriatrics, 50(3), 267-271.

Cheshire, A., Barlow, J., \& Powell, L. (2010a). Coping using positive reinterpretation in parents of children with cerebral palsy. Journal of Health Psychology, 15(6), 801-810.

Cheshire, A., Barlow, J. H., \& Powell, L .A. (2010b). The psychosocial well-being of parents of children with cerebral palsy: A comparison study. Disability and Rehabilitation, 32(20), 1673-1677.

Chronister, J., Chan, F., Sasson-Gelman, E. J., \& Chiu, C. Y. (2010). The association of stress-coping variables to quality of life among caregivers of individuals with traumatic brain injury. NeuroRehabilitation, 27(1), 49-62.

Cooper, C., Katona, C., Orrell, M., \& Livingston, G. (2008). Coping strategies, anxiety and depression in caregivers of people with Alzheimer's disease. International Journal of Geriatric Psychiatry, 23(9), 929-936.

Davis, E., Shelly, A., Waters, E., Boyd, R., Cook, K., Davern, M., et al. (2010). The impact of caring for a child with cerebral palsy: quality of life for mothers and fathers. Child: Care, Health and Development, 36(1), 63-73.

Eker, L., \& Tüzün, E. H. (2004). An evaluation of quality of life of mothers of children with cerebral palsy. Disabilility and Rehabilitation, 26(23), 1354-1349.

Florian, V., \& Findler, L. (2001). Mental health and marital adaptation among mothers of children with cerebral palsy. American Journal of Orthopsychiatry, 71(3), 358-367.

Grootenhuis, M. A., \& Bronner, M. B. (2009). Paediatric illness! Family matters. Acta Pediatrica, 98, 940-941.

Gutiérrez-Maldonado, J., Caqueo-Urízar, A., \& Kavanagh, D. J. (2005). Burden of care and general health in families of patients with schizophrenia. Social Psychiatry and Psychiatric Epidemiology, 40(11), 899-904.

Hanzawa, S., Bae, J. K., Tanaka, H., Bae, Y. J., Tanaka, G., Inadomi, H., et al. (2010). Caregiver burden and coping strategies for patients with schizo- phrenia: Comparison between Japan and Korea. Psychiatry Clinical Neuroscience, 64(4), 377-386.

Ketelaar, M., Volman, M. J., Gorter, J. W., \& Vermeer, A. (2008). Stress in parents of children with cerebral palsy: What sources of stress are we talking about? Child: Care, Health and Development, 34(6), 825-829.

King, G., King, S., Rosenbaum, P., \& Goffin, R. (1999). Family-centered caregiving and well-being of parents of children with disabilities: Linking process with outcome. Journal of Pediatric Psychology, 24(1), 41-53.

Lauber, C., Eichenberger, A., Luginbühl, P., Keller, C., \& Rössler, W. (2003). Determinants of burden caregivers of patients with exacerbating schizophrenia. European Psychiatry, 18(6), 285-289.

Majerovitz, S. D. (2007). Predictors of burden and depression among nursing home family caregivers. Aging $\mathcal{E}$ Mental Health, 11(3), 323-329.

Márquez-González, M., Losada, A., López, J., \& Peñacoba, C. (2009). Reliability and validity of the Spanish version of the Revised Scale for Caregiving Self-Efficacy. Clinical Gerontologist, 32(4), 347-357.

McCubbin, H. I., McCubbin, M. A., Patterson, J. M., Cauble, A. E., Wilson, L. R., \& Warwick, W. (1983). CHIP-Coping Health Inventory for Parents: An assessment of parental coping patterns in the care of the Chronically Ill Child. Journal of Marriage and Family, May, 359-370.

McCullagh, E., Brigstocke, G., Donaldson, N., \& Kalra, L. (2005). Determinants of caregiving burden and quality of life in caregivers of stroke patients. Stroke, 36(10), 2181-2186.

McEwen, B. S., \& Gianaros, P. J. (2010). Central role of the brain in stress and adaptation: Links to socioeconomic status, health, and disease. Annals of the New York Academy of Sciences, 1186, 190-222.

Mobarak, R., Khan, N. Z., Munir, S., Zaman, S. S., \& McConachie, H. (2000). Predictors of stress in mothers of children with cerebral palsy in Bangladesh. Journal of Pediatric Psychology, 25(6), 427-433.

Murphy, B., Herrman, H., Hawthorne, G., Pinzone, T., \& Evert, H. (2000). Australian WHOQoL instruments: User's manual and interpretation guide. Melbourne, Australia: Australian WHOQoL Field Study Centre. 
Musil, C. M. (1998). Health, stress, coping, and social support in grandmother caregivers. Health Care for Women International, 19(5), 441-455.

Myers, J. E. (2003). Coping with caregiving stress: A wellness-oriented, strengths-based approach for family counselors. The Family Journal, 11(2), 153161.

Odding, E., Roebroeck, M. E., \& Stam, H. J. (2006). The epidemiology of cerebral palsy: Incidence, impairments and risk factors. Disability and Rehabilitation, 28(4), 183-191.

Olson, D. H., Portner, J., \& Lavee, Y. (1985). FACES III. USA, Minnesota: St. Paul, University of Minnesota.

Olsson, M. B. \& Hwang, C. P. (2001). Depression in mothers and fathers of children with intellectual disability. Journal of Intellectual Disability Research, 45(6), 535-543.

Ones, K., Yilmaz, E., Cetinkaya, B., \& Caglar, N. (2005). Assessment of the quality of life of mothers of children with cerebral palsy (primary caregivers). Neurorehabilitation and Neural Repair, 19(3), 232-237.

Phipps, S., Dunavant, M., Lensing, S., \& Rai, S. N. (2005). Psycosocial predictors of distress in parents of children undergoing stem cell or bone marrow transplantation. Journal of Pediatric Psychology, 30(2), 139-153.

Pousada, M., Boixadós, M., Nieto, R., Muñoz-Marrón, E., Hernández, E., Gómez, B., et al. (2009). Proyecto de una intervención a través de la red para la mejora de la calidad de vida de padres cuidadores de niños con trastornos crónicos. RevistaeSalud. com, 5(20). Disponible en www.revistaesalud.com

Raina, P., O’Donell, M., Schawellnus, H., Rosenbaum, P., King, G., Brehaut, J., et al. (2004). Caregiving process and caregiver burden: Conceptual models to guide research and practice. BMC Pediatrics, 4(1), 1-13.

Raina, P., O'Donnell, M., Rosenbaum, P., Brehaut, J., Walter, S. D., Russell, D., et al. (2005). The health and well-being of caregivers of children with cerebral palsy. Pediatrics, 115(6), 626-636.

Rethlefsen, S. A., Ryan, D. D., \& Kay, R. M. (2010). Classification systems in cerebral palsy. Orthopedic Clinics of North America, 41(4), 457-467.
Rigby, H., Gubitz, G., \& Phillips, S. (2009). A systematic review of caregiver burden following stroke. International Journal of Stroke, 4(4), 285-292.

Rivera-Navarro, J., Benito-León, J., Oreja-Guevara, C., Pardo, J., Dib, W. B., Orts, E., et al. (2009). Burden and health-related quality of life of Spanish caregivers of persons with multiple sclerosis. Multiple Sclerosis, 15(11), 1347-1355.

Sánchez-Sosa, J., \& González-Celia, A. (2006). Evaluación de la calidad de vida desde la perspectiva psicológica. En V. E. Caballo (Ed.), Manual para la evaluación clínica de los trastornos psicológicos. Trastornos de la edad adulta e informes psicológicos (pp. 473-492). Madrid: Pirámide.

Seguí J. D., Ortiz-Talo, M., \& de Diego, Y. (2008). Factores asociados al estrés del cuidador primario de niños con autismo: sobrecarga, psicopatología y estado de salud. Anales de Psicología, 24(1), 100-105.

Snider, L., Majnemer, A., \& Darsaklis, V. (2010). Virtual reality as a therapeutic modality for children with cerebral palsy. Developmental NeuroRehabilitation, 13(2), 120-128.

Spielberger, C. D., Gorsuch, R. L., \& Lushene, R. E. (2008). STAI. Cuestionario de Ansiedad Estado-Rasgo. Madrid: TEA.

Steffen, A. M., McKibbin, C., Zeiss, A. M., Gallagher-Thompson, D., \& Bandura, A. (2002). The Revised Scale for Caregiving Self-Efficacy: Reliability and validity studies. Journal of Gerontology: Psychological Sciences, 57B(1), 74-86.

Sun, F., Kosberg, J. I., Kaufman, A. V., \& Leeper, J. D. (2010). Coping strategies and caregiving outcomes among rural dementia caregivers. Journal of Gerontological Social Work, 53(6), 547-567.

Surveillance of Cerebral Palsy in Europe. (2002). Prevalence and characteristics of children with cerebral palsy in Europe. Developmental Medicine \& Child Neurology, 44(9), 633-640.

Terra, V. C., Cysneiros, R. M., Schwartzman, J. S., Teixeira, M. C., Arida, R. M., Cavalheiro, E. A., et al. (2011). Mothers of children with cerebral palsy with or without epilepsy: A quality of life perspective. Disability and Rehabilitation, 33(5), 384-388.

Tucker, C. M., Butler, A. M., Loyuk, I. S., Desmond, F., \& Surrency, S. L. (2009). Predictors of a health-promoting lifestyle and behaviours among 
low-income of chronically ill children. Journal of the National Medical Association, 101(2), 103-110.

Tuna, H., Unalan, H., Tuna, F., \& Kokino, S. (2004). Quality of life of primary caregivers of children with cerebral palsy: A controlled study with Short Form-36 Questionnaire. Developmental Medicine \& Child Neurology, 46(9), 647-648.

Unsal-Delialioglu, S., Kaya, K., Ozel, S., \& Gorgulu, G. (2009). Depression in mothers of children with cerebral palsy and related factors in Turkey: A controlled study. International Journal of Rehabilitation Research, 32(3), 199-204.

Vázquez, C., \& Sanz, J. (1999). Fiabilidad y validez de la versión española del Inventario para la Depresión de Beck de 1978 en pacientes con trastornos psicológicos. Clínica y Salud, 10(1), 59-81.

Vincent, C., Desrosiers, J., Landreville, P., \& Demers, L. (2009). Burden of caregivers of people with stroke: Evolution and predictors. Cerebrovascular Diseases, 27(5), 456-464.

Wang, H., \& Jong, Y. (2004). Parental stress and related factors in parents of children with cerebral palsy. The Kaohsiung Journal of Medical Sciences, 20(7), 334-340.

Zarit, S. H., Reever, K. E., \& Bach-Peterson, J. (1980). Relatives of the impaired elderly: Correlates of feelings of burden. The Gerontologist, 20(6), 649-655. 
